\title{
STERILITY AND PARTHENOCARPY IN DIPLOID HYBRIDS OF MUSA
}

\author{
K. S. DODDS and N. W. SIMMONDS \\ Imperial College of Tropical Agriculture, Trinidad, B.W.I.
}

\section{INTRODUCTION}

Received I0.xi.47

Bananas can be divided into two groups according to the ways in which their fruit develop. In the one group-which contains all edible bananas-vegetative parthenocarpy occurs; that is, an unpollinated ovary automatically grows into a fruit, of which the loculi are filled with edible pulp. In the following account, plants with this behaviour are called " parthenocarpic" or, alternatively, " edible." The majority of parthenocarpic (edible) bananas do not contain seed even after pollination, while the few exceptions set far fewer seed than wild species.

In the other group-which contains all the wild species-a flower must be effectively pollinated to form a fruit. And, of course, in this case, the fruit is filled with seed. Plants with this behaviour are called " non-parthenocarpic" or, alternatively, "seeded." If the flower is unpollinated, the ovary may persist for a month or two but, after the ovules have disintegrated, it is merely an empty chamber that eventually shrivels.

Fertility, male and female, has been compared in five edible diploid bananas by Dodds (1943). All were highly female-sterile and only one (Accession No. I.R. 143) produced viable pollen plentifully. This last, namely Pisang Lilan, was cytologically the least complex and appeared to be heterozygous for a single interchange and possibly an inversion. It has now been crossed with three of its relatives, seeded types of Musa acuminata Colla, and the cytogenetics of the hybrids are described in this paper. The data are used to advance the analysis of the two factors of major importance in the genetic system of the banana complex-sterility and parthenocarpy.

\section{MATERIAL AND METHODS}

The series of hybrids between clones of $M$. acuminata * were as on page 102 .

In studying the cytology of the hybrids, considerable technical difficulty was encountered. Fixation of smears in Craf, Navashin,

* Descriptions of these clones, with accession numbers from the Introductions Register of Musa Material of this Institution are given by Cheesman (1947). Type and accession numbers were used in earlier publications of the authors pending Dr Cheesman's taxonomic revision of the genus. 
Langlet and $2 \mathrm{BE}$, followed by crystal violet-iodine staining, gave irregular results which were a characteristic artefact peculiar to the material. The same techniques gave very satisfactory results in the

\begin{tabular}{|c|c|c|c|c|c|}
\hline Female (seeded) & Accession no. & $\mathrm{Ma}$ & ale (edible) & Accession no. & Hybrid families \\
\hline $\begin{array}{cl}\text { Clone } & \text { Selangor } \\
\text {, } & \text { Calcutta } 4 \\
\text { ", } & \text { Long Tavoy } \\
\text {, } & \text { Selangor }\end{array}$ & 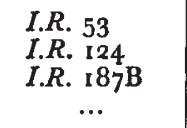 & $\begin{array}{c}\text { Clone } \\
\text {," } \\
\text {," }\end{array}$ & $\begin{array}{c}\text { Pisang Lilan } \\
\text {," ", } \\
\text { Cal"cutta " }\end{array}$ & $\begin{array}{c}\text { I.R. I } 43 \\
,, \\
, "\end{array}$ & $\begin{array}{l}206, \text { (I) to (ro) } \\
265, \text { (I) to }(26) \\
426 \mathrm{~A}, \text { (I) to ( } 7) \\
\text { I plant }\end{array}$ \\
\hline
\end{tabular}

parents. Moreover, the uncertainty of the result was greater in the wider cross ; for example, whereas most numbers of 206 gave fair or good results with chromacetic fixation, few did so in 265 . Similar difficulty in fixing hybrid material has been noted by other workers.

The technique finally adopted was pre-fixation in $1: 3$ aceticalcohol followed by staining in carmine.

\section{GENETICAL RESULTS : PARTHENOCARPY}

The behaviour of unpollinated flowers of the parental clones followed three developmental sequences :-

(I) Parthenocarpic: in Pisang Lilan, the ovaries swell and become filled with edible pulp to give mature parthenocarpic fruits in about three months.

(2) Persistent : in Calcutta 4 and Long Tavoy, they swell slightly, persist for two or three months although the ovules degenerate, and finally rot.

(3) Shrivelling : in Selangor, they shrivel within a month.

The products of unpollinated flowers of the hybrids showed every family as segregated into the three classes. However, shrivellers (of which there were few), varied widely between themselves in the time at which rotting began. They could not always be certainly distinguished from persistents and so the two classes were combined as "non-parthenocarpic" for the analysis of the genetic data.

The amount, distribution and time of development of edible pulp in parthenocarpic fruits varied from some in which small nodules of edible pulp were formed late in development to others rapidly filled with edible pulp ( $c f$. Dodds, 1943, r945, on plant I590 ; and Dodds and Simmonds, 1946, on S.H. 62). Nevertheless, according to the sole criterion of the development of edible pulp, the distinction between parthenocarpic and non-parthenocarpic was distinct enough.

The results are presented in table 1 . The $\chi^{2}$ test shows that 206 and 265 agree with a hypothetical I : I ratio but that 426 A does not, giving instead a ratio of about io non-parthenocarpic plants : I parthenocarpic plant. Selfing and crossing of seeded types of $M$. acuminata give no parthenocarpic progeny (Cheesman, personal communication). In 206 and 265, parthenocarpy may therefore be 
ascribed to the action of a single dominant gene, herein denoted $\mathbf{P}$, for which all the parthenocarpic siblings are heterozygous like their male parent Pisang Lilan. In addition there must be a number of

TABLE I

Segregation for parthenocarpy

\begin{tabular}{|c|c|c|c|c|c|}
\hline Family & Parthenocarpic & Not parthenocarpic & Total & $x^{2}(1: 1)$ & $P$ \\
\hline 206 & 5 & 5 & 10 & $\ldots$ & $\ldots$ \\
265 & 19 & 22 & 41 & $\ldots$ & $\ldots$ \\
& 24 & 27 & 51 & $0 \cdot 18$ & $0 \cdot 70$ \\
$426 \mathrm{~A}$ & 3 & 29 & 32 & $21 \cdot 2$ & $0 \cdot 02$ \\
\hline
\end{tabular}

modifiers that influence the amount of parthenocarpic development. In $426 \mathrm{~A}$, the genetical situation is more complex owing, presumably, to an initial genetic difference between Long Tavoy and the other two seeded clones.

Parthenocarpic development does not invariably go with complete female sterility. For example, pollinated fruits of 206 (I), 206 (7) and 206 (9) contained about I-Io good seeds per ovary. Development of seed was conditional upon the chance of pollination. Parthenocarpic and seedless fruits of 206 (I) were only about two-thirds of the volume of its parthenocarpic fruits with seed from pollinated flowers. Pollinated and unpollinated flowers of 206 (7) and 206 (9), on the other hand, gave fruits of the same size but the pollinated fruits had fewer seeds than those of $206(\mathrm{I})$. These plants therefore promise to provide a useful approach to the analysis of fruit development.

\section{FERTILITIES}

(i) Seed yields of the parents

Available data on seed yields of the parents when selfed, crosspollinated between themselves, and with pollen of some of their hybrids are summarised in table 2. Each ovary contained about I 30 ovules and so "Good seeds per ovary" is taken as a direct index of female fertility.

It will be seen that (I) selfing and intercrossing of Selangor, Calcutta 4, Long Tavoy and Pisang Lilan gave comparable and relatively high yields of seed and (2) the hybrids 265,206 (9) and 206 (Io) were effective male parents.

\section{(ii) Seed yields of the hybrids}

Table 3 summarises available data on the female fertilities of the hybrids, with parthenocarpic and non-parthenocarpic siblings segregated. As already noted, parthenocarpy does not necessarily 
TABLE 2

Female fertilities of the maternal parents and Selangor $\times$ Calcutta 4

In each group of three entries, the upper figure is the number of ovaries, the middle (italics) and lower (bold-face) figures are the numbers of good and bad seeds per ovary. All plants have about 130 ovules per ovary.

\begin{tabular}{|c|c|c|c|c|c|c|c|c|}
\hline \multirow{2}{*}{$\begin{array}{c}\text { Female } \\
\text { parent }\end{array}$} & \multicolumn{8}{|c|}{ Male parent } \\
\hline & Selangor & Calcutta 4 & $\begin{array}{l}\text { Long } \\
\text { Tavoy }\end{array}$ & $\begin{array}{c}\text { Pisang* } \\
\text { Lilan }\end{array}$ & $\begin{array}{l}\text { Selangor } \times \\
\text { Calcutta } 4\end{array}$ & 265 & $206(9)$ & $206(10)$ \\
\hline Selangor & $\begin{array}{c}136 \\
50 \cdot 0 \\
3 \cdot 7\end{array}$ & $\cdots$ & $\begin{array}{l}48 \\
58 \cdot 4 \\
0.0\end{array}$ & $\begin{array}{l}36 \\
50.5 \\
0.7\end{array}$ & $\cdots$ & $\cdots$ & $\begin{array}{l}31 \\
16 \cdot x \\
x \cdot 3\end{array}$ & $\begin{array}{l}28 \\
34 \cdot 5 \\
0.6\end{array}$ \\
\hline Calcutta $4 \dagger$ & $\begin{array}{l}119 \\
30 \cdot 0 \\
28.9\end{array}$ & $\begin{array}{l}85 \\
76 \cdot 9 \\
2 \times \cdot 4\end{array}$ & $\begin{array}{r}128 \\
86 \cdot 2 \\
1 \cdot 7\end{array}$ & $\begin{array}{l}45 \\
40 \cdot 2 \\
3^{6 \cdot 0}\end{array}$ & $\cdots$ & $\begin{array}{l}13^{8} \\
39 \cdot 8 \\
16 \cdot 1\end{array}$ & $\begin{array}{l}44 \\
42 \cdot 5 \\
41 \cdot 9\end{array}$ & $\begin{array}{l}40 \\
38 \cdot 3 \\
3^{6} \cdot 7\end{array}$ \\
\hline $\begin{array}{l}\text { Long } \\
\text { Tavoy }\end{array}$ & $\cdots$ & $\cdots$ & $\begin{array}{r}112 \\
46.8 \\
\times \cdot 5\end{array}$ & $\begin{array}{l}43 \\
44 \cdot 7 \\
\times \cdot 8\end{array}$ & $\cdots$ & $\cdots$ & $\cdots$ & $\cdots$ \\
\hline $\begin{array}{c}\text { Selangor } \ddagger \\
\times \\
\text { Calcutta } 4\end{array}$ & $\begin{array}{l}99 \\
24.0\end{array}$ & $\begin{array}{c}178 \\
27 \cdot 4\end{array}$ & $\cdots$ & $\cdots$ & $\begin{array}{l}87 \\
35.4\end{array}$ & $\cdots$ & $\cdots$ & $\cdots$ \\
\hline
\end{tabular}

* Female sterile (Dodds I943, 1945).

$\dagger$ Calcutta $4 \times 265$ : average of pollinations by 15 different members of 265 .

¥ Data from Dodds and Pittendrigh, 1945 ; no record of bad seeds.

TABLE 3

Summary of seed yields in backcrosses of the hybrid families

After dash, numbers of siblings; the numbers of seeds per ovary in the classes with non-parthenocarpic fruits are given in bold type.

\begin{tabular}{|c|c|c|c|c|c|}
\hline \multicolumn{2}{|c|}{ Backcross } & \multirow{2}{*}{$\begin{array}{c}\text { Numbers } \\
\text { of } \\
\text { ovaries }\end{array}$} & \multicolumn{2}{|c|}{ Good seeds per ovary } & \multirow{2}{*}{$\begin{array}{l}\text { Bad } \\
\text { seeds }\end{array}$} \\
\hline Female & Male & & Mean & $\begin{array}{c}\text { Range of means } \\
\text { between sibs }\end{array}$ & \\
\hline $\begin{array}{l}206-5 \\
206-5\end{array}$ & Selangor & $\begin{array}{r}98 \\
\mathbf{6} 68\end{array}$ & $\begin{array}{r}1 \cdot 8 \\
\times 7 \cdot 7\end{array}$ & $\begin{array}{c}0 \cdot 0-5 \cdot 2 \\
12 \cdot 3-3 I \cdot 2\end{array}$ & $\begin{array}{l}1 \cdot 4 \\
3.8\end{array}$ \\
\hline $\begin{array}{l}206-5 \\
206-5\end{array}$ & $\begin{array}{l}\text { Pisang } \\
\text { Lilan }\end{array}$ & $\begin{array}{l}136 \\
186\end{array}$ & $\begin{array}{r}1 \cdot 5 \\
\times 4 \cdot 2\end{array}$ & $\begin{array}{c}0 \cdot 0-3 \cdot 0 \\
12 \cdot 6-21 \cdot 1\end{array}$ & $\begin{array}{l}I \cdot 1 \\
4 \cdot 3\end{array}$ \\
\hline $\begin{array}{l}265-16 \\
265-\times 3\end{array}$ & Calcutta 4 & $\begin{array}{l}426 \\
664\end{array}$ & $\begin{array}{l}0.3 \\
0.5\end{array}$ & $\begin{array}{l}0.0-2.8 \\
0.0-2.6\end{array}$ & $\begin{array}{l}I \cdot I \\
I \cdot 2\end{array}$ \\
\hline $\begin{array}{l}265-16 \\
265-13\end{array}$ & $\begin{array}{l}\text { Pisang } \\
\text { Lilan }\end{array}$ & $\begin{array}{l}428 \\
602\end{array}$ & $\begin{array}{l}0.1 \\
0.2\end{array}$ & $\begin{array}{l}0.0-1 \cdot 8 \\
0.0-1 \cdot 2\end{array}$ & $\begin{array}{l}0 \cdot 7 \\
\times \cdot 2\end{array}$ \\
\hline $\begin{array}{l}426 \mathrm{~A}-2 \\
426 \mathrm{~A}-8\end{array}$ & $\begin{array}{l}\text { Long } \\
\text { Tavoy }\end{array}$ & $\begin{array}{r}73 \\
326\end{array}$ & $\begin{array}{l}0.1 \\
1.4\end{array}$ & $\begin{array}{l}0.0-0.3 \\
0.0-8.0\end{array}$ & $\begin{array}{l}0.9 \\
6.4\end{array}$ \\
\hline $\begin{array}{l}426 \mathrm{~A}-2 \\
426 \mathrm{~A}-8\end{array}$ & $\begin{array}{l}\text { Pisang } \\
\text { Lilan }\end{array}$ & $\begin{array}{r}89 \\
336\end{array}$ & $\begin{array}{l}0.0 \\
0.3\end{array}$ & $\begin{array}{l}0.0-0.0 \\
0.0-1.6\end{array}$ & $\begin{array}{l}I \cdot 0 \\
4 \cdot 0\end{array}$ \\
\hline
\end{tabular}


go with complete female sterility, but parthenocarpic types consistently gave lower seed yields than non-parthenocarpic. A comparison of tables 2 and 3 shows that non-parthenocarpic members of 206 gave markedly lower seed yields than the seeded parent, Selangor. Nonparthenocarpic members of 265 and $426 \mathrm{~A}$ were even less fertile.

Table 2 also includes data on the selfing and backcrossing of the $F_{1}$ plant of Selangor $\times$ Calcutta 4 . It was appreciably less fertile than either parent and this can now be correlated, as described below, with cytological differences between the two clones.

\section{(iii) Male fertilities}

The usual procedure of assessing male fertility by counting " good" and "bad" pollen grains cannot be used in Musa because it is impossible to estimate their relative numbers from the broken relics to which inviable grains give rise in the mature anther. To overcome this difficulty Dodds (r 943 ) counted the numbers of pollen mother cells and pollen grains in whole anthers. The method is so laborious that all these clones are assumed to have about 2200 pollen mother cells per anther as found in Selangor and Pisang Lilan, and only a few pollen grain counts have been made, as follows :-

\begin{tabular}{|c|c|c|c|}
\hline Material & $\begin{array}{l}\text { Pollen grains } \\
\text { per anther }\end{array}$ & $\begin{array}{l}\text { Fertility } \\
\text { per cent. }\end{array}$ & Remarks \\
\hline $\begin{array}{l}\text { Selangor } \\
\text { Long Tavoy : } \\
\text { Pisang Lilan : } \\
\text { Selangor } \times \text { Calcutta } \\
206 \text {. } \\
265 .\end{array}$ & $\begin{array}{r}9,300 \\
12,300 \\
4,000 \\
3,500 \\
5,300 \\
1,900\end{array}$ & $\begin{array}{r}100 \\
100 \\
\pm 50 \\
\pm 40 \\
\pm 60 \\
\pm 20\end{array}$ & $\begin{array}{l}\text { Dodds (1943) } \\
\text { Estimated from part of a single anther } \\
\text { Dodds (1943) } \\
\text { From two thecæ, } 1850 \text { and } 1600 \\
\text { From mean of } 4 \text { thecæ from } 4 \\
\text { different plants. Range } 1200-3600 \\
\text { From mean of } 5 \text { thecr from } 5 \\
\text { different plants. Range } 450-1450\end{array}$ \\
\hline
\end{tabular}

No actual counts were made of $426 \mathrm{~A}$, but its members seemed about as male-sterile as 265 .

\section{CYTOLOGICAL RESULTS}

(i) The parents

Eleven bivalents were present in all the observed metaphases of Calcutta 4 and Selangor, but one out of 20 cells of Long Tavoy contained ten bivalents and two univalents. Disjunction was regular in the vast majority of cells. In Selangor, however, I cell in 52 showed two lagging univalents and in Calcutta 4 anaphase bridges were seen; they were rare and without visible fragments. Minor structural heterozygosity is not unexpected in a highly outbred group. They produce abundant good pollen and may be regarded as fully male fertile. 
Metaphase behaviour in Pisang Lilan has been shown previously to be compatible with heterozygosity for a single interchange (Dodds, I943; Dodds and Simmonds, I946 and table 4). However, the potential ring of four chromosomes did not occur in the 103 cells that were examined. Anaphase bridges occurred in about onequarter of the cells but no fragments were associated with them (table 6). In the many preparations examined, one small group of polyploid cells was seen, resulting from the type of restitution described by Dodds and Simmonds (1946).

TABLE 4

Structural complexities of parents and hybrids : as minimal estimates

Numbers of siblings are given for the hybrids; bold-face type signifies that the siblings are deducible as potential ring of four plus ring of six types (see text).

\begin{tabular}{|c|c|c|c|c|c|}
\hline \multirow{4}{*}{ Plant material } & \multicolumn{5}{|c|}{ Potential rings } \\
\hline & o & (4) & 2. (4) & (6) & $(4)+(6)$ \\
\hline & \multicolumn{5}{|c|}{ Critical observed configurations } \\
\hline & IIII & $\begin{array}{l}\mathrm{III}+9 \mathrm{II}+\mathrm{I} \\
\text { or IV+gII }\end{array}$ & $I V+I I I+\eta I I+I$ & $2 I I I+8 I I$ & $\mid \begin{array}{l}3 I I I+6 I I+I \text { or } \\
I V+2 I I I+6 I I\end{array}$ \\
\hline 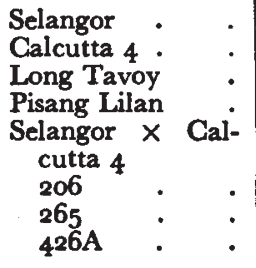 & $\begin{array}{l}\underset{x}{x} \\
x \\
x\end{array}$ & 9 & I & $\begin{array}{r}1 x \\
3\end{array}$ & $\begin{array}{r}15 \\
4\end{array}$ \\
\hline
\end{tabular}

(ii) The hybrids

Selangor $\times$ Calcutta 4. First metaphases in this $F_{1}$ hybrid were somewhat mistimed and correspondingly difficult to analyse, but there was clear evidence that it is heterozygous for a minimum of two independent interchanges (table 4). Univalents occurred in about I5 per cent. of the cells. Anaphase bridges were not seen but I5 per cent. of the cells showed numerical non-disjunction (table 6).

206. Several members of 206 showed delayed spiralisation during prophase, clumping and misorientation during metaphase, and irregular spindles at anaphase.

With the exception of 206 (9), the first division of meiosis was similar to that of Pisang Lilan, the paternal parent. 206 (I) and 206 (5) had comparatively high frequencies of associations of four. Most were chains, but in 206 ( 1 ), one appeared to be a ring and another a chain of two attached at one end to a ring of two by a 
common chiasma. Most of the associations of three were chains as in Pisang Lilan, but two other forms, "cross" and "frying-pan," occurred very rarely. These configurations imply crossing over in an interstitial segment or reduplicated segments of the pairing arms (Darlington and Gairdner, 1937 ; Stebbins and Ellerton, 1939).

TABLE 5

Summary of metaphase data for Pisang Lilan, its hybrids and Selangor $\times$ Calcutta 4 Number of plants in bold-face type

\begin{tabular}{|c|c|c|c|c|c|c|c|}
\hline \multirow{2}{*}{ Plant or cross } & \multirow{2}{*}{ Interchanges } & \multirow{2}{*}{ Total cells } & \multicolumn{5}{|c|}{ Frequencies per nucleus of } \\
\hline & & & I & II & III & IV & V \\
\hline $\begin{array}{l}\text { Pisang Lilan }: \\
206-9-: \\
206(9)-\mathrm{I} \text { : } \\
\text { Selangor } \times \text { Calcutta } 4: \\
265-26 . \\
426 \mathrm{~A}-7 .\end{array}$ & $\begin{array}{l}\text { I } \\
\text { I } \\
0 \\
2 \\
3 \\
3 \\
3(?)\end{array}$ & $\begin{array}{r}103 \\
320 \\
141 \\
57 \\
338 \\
71\end{array}$ & $\begin{array}{l}0.75 \\
0.74 \\
\cdots \\
0.83 \\
0.73 \\
1.25\end{array}$ & $\begin{aligned} 10 \cdot 08 \\
10 \cdot 00 \\
11.00 \\
9 \cdot 67 \\
8.44 \\
7.48\end{aligned}$ & $\begin{array}{l}0 \cdot 34 \\
0 \cdot 34 \\
\ldots \\
0 \cdot 44 \\
\mathrm{I} \cdot 34 \\
\mathrm{I} \cdot 78\end{array}$ & $\begin{array}{l}0 \cdot 01 \\
0 \cdot 05 \\
\ldots .6 \\
0 \cdot 16 \\
0 \cdot 07 \\
0 \cdot 10\end{array}$ & $\begin{array}{l}\ldots \\
\cdots \\
\cdots \\
0.00 \\
0.01\end{array}$ \\
\hline
\end{tabular}

The effective structural homozygosity of 206 (9), (tables 4 and 5), combined with parthenocarpy and diploidy is conclusive proof of the independence of parthenocarpy, structural hybridity and polyploidy in the banana complex (Dodds, I943). Evidently Pisang Lilan produces two kinds of gametes, one with a genome essentially identical with a genome of Selangor and the other differing from it by one interchange.

TABLE 6

Summary of first anaphase data for Pisang Lilan, its hybrids and Selangor $\times$ Calcutta 4

Numbers of siblings in bold-face type

\begin{tabular}{|c|c|c|c|c|c|c|c|}
\hline \multirow{2}{*}{ Plant or family } & \multicolumn{5}{|c|}{ Anaphases } & \multicolumn{2}{|c|}{$\begin{array}{l}\text { Means per } \\
\text { nucleus of }\end{array}$} \\
\hline & Regular & $\begin{array}{l}\text { Univ.(s) } \\
\text { only }\end{array}$ & $\begin{array}{c}\text { Bridge(s) } \\
\text { only }\end{array}$ & $\begin{array}{l}\text { Univ.(s) } \\
\text { and } \\
\text { bridge(s) }\end{array}$ & Totals & Univs. & Bridges \\
\hline $\begin{array}{l}\text { Pisang Lilan } \\
206-9 \cdot \\
206(9)-1 \\
265-26 . \\
426 \mathrm{~A}-7 \\
\text { Selangor } \times \text { Cal- } \\
\text { cutta } 4\end{array}$ & $\begin{array}{r}97 \\
234 \\
158 \\
795 \\
205 \\
59\end{array}$ & $\begin{array}{r}52 \\
111 \\
1 \\
285 \\
63 \\
10\end{array}$ & $\begin{array}{r}44 \\
74 \\
1 \\
107 \\
42 \\
0\end{array}$ & $\begin{array}{r}3 \\
8 \\
0 \\
21 \\
11 \\
0\end{array}$ & $\begin{array}{r}196 \\
427 \\
160 \\
1208 \\
321 \\
69\end{array}$ & $\begin{array}{l}0.30 \\
0.29 \\
0.01 \\
0.25 \\
0.27 \\
0.15\end{array}$ & $\begin{array}{l}0.24 \\
0.19 \\
0.01 \\
0.11 \\
0.17 \\
0.00\end{array}$ \\
\hline
\end{tabular}

265 and $426 \mathrm{~A}$. Every plant proved to be heterozygous for interchange but the absence of closed associations makes an exact definition of the sizes of the potential rings impossible. The highest 
association actually seen was a chain of five chromosomes in a cell of 265 (18). Of the 26 siblings of 265 , I 5 appeared to be heterozygous for three interchanges of which two affected one pair of chromosomes. At a minimal estimate, these plants could presumably form two rings-of six and four chromosomes (table 4). In the remaining I I plants, metaphase data merely indicated a potential ring of six (table 4).

Selangor and Pisang Lilan differ by a single interchange which is heterozygous in the latter and the two interchanges in Selangor $\times$ Calcutta 4 are independent, maximal association being two separate rings of four. Clearly, therefore, in the hybrids of Calcutta $4 \times$ Pisang Lilan, one of the interchanges concerned in the potential ring of six must be derived from Pisang Lilan. In other words, all the siblings of 265 must have the interchange for which Pisang Lilan is heterozygous. And they will also have the two interchanges representing homozygous segmental differences between Selangor and Calcutta 4 . It is concluded therefore that every member of 265 was heterozygous for three interchanges and that the interchange gamete from Pisang Lilan functioned in each case.

$426 \mathrm{~A}$ may have the same constitution as 265 . Direct proof of the segmental identity of Calcutta 4 and Long Tavoy is not yet available but the data on seed yields given in table 2 and an examination of phenotypes suggest a close relationship, closer for instance than that subsisting between Calcutta 4 and Selangor. It will be noted that pollen from Long Tavoy gave a higher yield of seed per ovary with Calcutta 4 than did pollen from Calcutta 4 itself.

In these hybrids, associations of three chromosomes were usually convergently oriented chains. About 7 per cent. were armed structures with multiple chiasmata so that chiasmata in interstitial and differential segments were evidently more frequent than in Pisang Lilan and 206. Chains of four were both convergent and linear.

At anaphase, some cells of every plant showed lagging univalents. Bridges were generally less common than in Pisang Lilan and 206 and, indeed, no bridges at all were observed in 265 (4).

\section{(iv) Mistiming of the first division}

In the seeded diploids, there is a short but definite diakinesis with the nucleolus free and greatly reduced in size and the eleven bivalents distributed throughout the nucleus. The nuclear membrane disappears and the bivalents, after being rather clumped at prometaphase, are oriented on the plate.

In all the hybrids of families 265 and $426 \mathrm{~A}$, the sequence of events during the first division was variably abnormal. In the more extreme cases of mistiming, diakinesis was not observed. When the nuclear membrane disappeared a tangled mass of partly condensed chromo- 
somes lay free in the cytoplasm, sometimes associated with a nucleolar remnant. Loops of chromatin sometimes emerged from this knot and occasionally there were metaphase-like chromosomes lying free but close to it. More rarely the partly condensed chromosomes lay in a single group but relatively free from one another. Spindles were sometimes associated with the knot. Spiralisation was incomplete at the time orientation began and was continued on the semblance of a metaphase plate (fig. I). Most metaphases were compact with
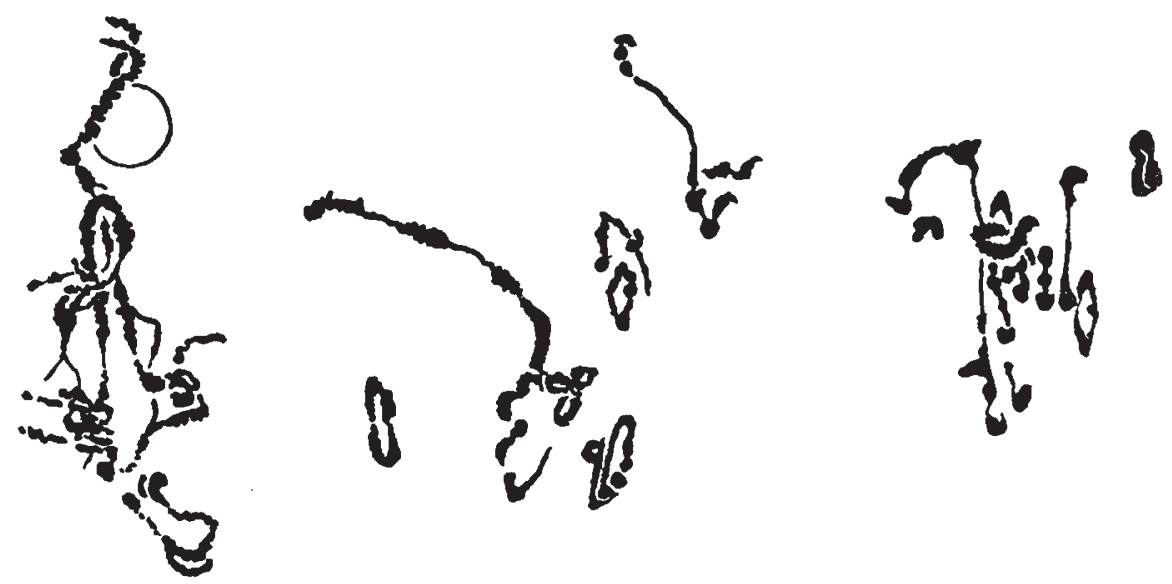

Fig. 1. - Stages in the development of a mistimed metaphase. $\times 3300$.

the chromosomes closely crowded and misoriented and the degree of condensation of the various associations was extremely variable. Some metaphases showed partial non-congression (fig. 2).

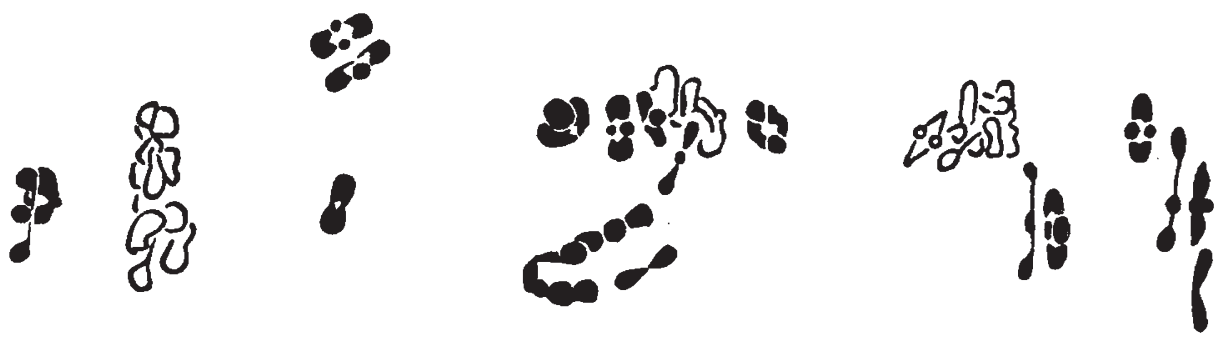

FIG. 2.-Metaphases showing misorientation. $\times 3300$.

The spindles associated with these metaphases were often morphologically abnormal, with the irregularities varying both in type and in intensity. For example, striæ were not parallel and seemed to cross one another; or poles were incompact and in extreme cases gave divergent spindles. Even with compact poles, the spindles were sometimes asymmetric or curved. Not infrequently they appeared to be markedly broader than the metaphase plate ; and, occasionally, within one cell, separate groups of chromosomes were associated with 
distinct spindles. Similar abnormalities have been described and illustrated in other hybrids of Musa by Dodds and Simmonds (r946).

As a result of these misbehaviours, early anaphases appeared disorderly, but two polar groups of daughter bivalents were successfully formed. Very occasionally anaphase failed after the initial separation of daughter bivalents had occurred, with the result that they were scattered in the cell; three examples of this were seen in 265 .

Errors of spiralisation were less marked or absent in some members of 265 and $426 \mathrm{~A}$ but nevertheless orientation and co-ordination of movement were irregular. Likewise, 206 showed only traces of mistiming.

Congression, orientation and movement were normal in all the second divisions that were examined.

\section{ANALYSIS OF STRUCTURAL HYBRIDITY}

\section{(i) Interchange}

As work on Musa progresses, the importance of interchange in the differentiation of the acuminata complex becomes more evident, and therefore the assignment of structural formulæ to the plants used in this study is worthwhile.

After Darlington and Gairdner (1937), Selangor may be taken as the basic homozygote and its segmental structure represented thus :-
$\mathrm{AB}$
$\mathrm{AB}$
CD EF
GH
KL $\quad \mathrm{MN}$
KL MN
etc.

Pisang Lilan and 206, except plant (9) would then be

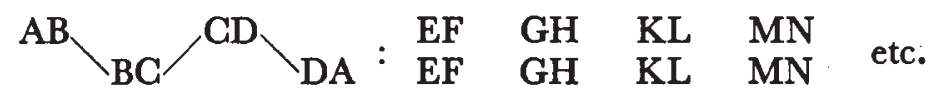

Calcutta 4, an interchange homozygote may be represented as

$\begin{array}{lllllll}\text { FB } & \text { GD } & \text { AE } & \text { LG } & \text { HK } & \text { MN } & \text { etc. } \\ \text { FB } & \text { GD } & \text { AE } & \text { LG } & \text { HK } & \text { MN } & \end{array}$

Whence Selangor $\times$ Calcutta 4 is

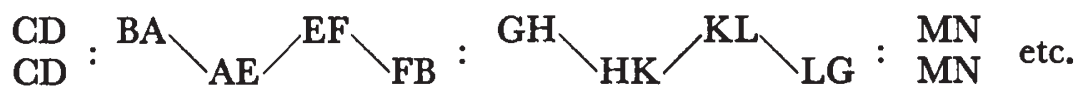

And 265,

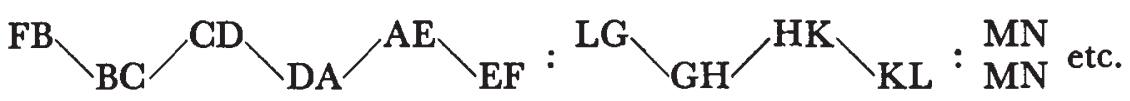

$4^{26} \mathrm{~A}$ may be similar to 265 . 


\section{(ii) Sterility and interchange}

The fertility of an interchange heterozygote is conditional upon the behaviour of the altered chromosomes (Koller, I944; Thompson and Hutcheson, 1942; Darlington and Gairdner, 1937). Full gametic fertility can only be attained when first, there are full multiple associations of disjunctional rings or chains and secondly, chiasmata are limited to the terminal segments.* Varying degrees of gametic sterility arise when these two conditions are not satisfied. In these interchange hybrids of Musa, the first condition is not satisfied, and the fact that the associations of three, four and five chromosomes were very commonly convergently co-oriented suggests that their fertility is limited by chromosome association rather than by the mechanics of orientation. The second condition has been inferred from various organisms wherein chiasma formation in interstitial and differential segments is responsible for sterility, e.g. Pisum, Zea and Datura. Configurations indicating such crossing over have been infrequent in the present material. In the following calculations, therefore, it is assumed that all multiple associations have regular convergent orientation, that chiasmata in interstitial and differential segments are of negligible frequency, that all the observed sterility arises from failure of association in terminal segments and that all univalents result from this failure of association.

Before attempting to correlate data on the fertility and cytology of the hybrids, the behaviour of univalents must be considered.

The behaviour of univalents. A comparison of tables 5 and 6 shows that in every hybrid there is a marked reduction in the frequency of identifiable univalents between metaphase and anaphase. A series of $\chi_{c}^{2}$ tests of $2 \times 2$ contingency tables comparing the frequencies of cells with and without identifiable univalents at metaphase and anaphase, gives the following results :-

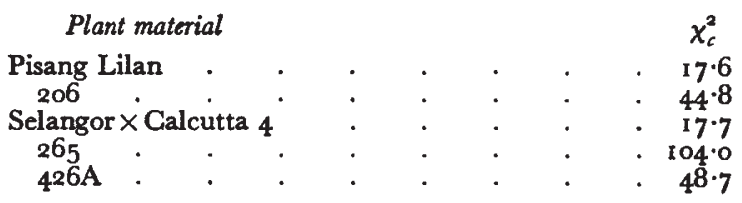

They are all highly significant at the 0.001 level : there is good evidence, therefore, that not all metaphase univalents remain to lag at anaphase. Some are passively carried to the poles in the separating anaphase groups. This carriage is assumed to be at random and the further assumption is made that lagging univalents divide at the first division and their daughter chromosomes are included at random in the nuclei at second telophase.

The calculation of gametic fertilities. Sixty per cent. of metaphase univalents of Pisang Lilan were included randomly in the polar groups

* The usage of terminal, interstitial and differential segment follows that of Darlington (1936). 
at telophase. Then, with the assumptions stated above, a calculation of its gametic fertility may be made after the manner of Koller (1944).

\begin{tabular}{|c|c|c|c|}
\hline Configuration & Per cent. cells & $\begin{array}{l}\text { Per cent. viable } \\
\text { products }\end{array}$ & Per cent. fertility \\
\hline \multirow[t]{2}{*}{$\begin{array}{c}\text { I III } \\
\text { I III, 2I } \\
\text { 9II, IIV } \\
\text { 9II, IIII, I I } \\
\text { 9II, 4I }\end{array}$} & $\begin{array}{r}44 \cdot 6 \\
18 \cdot 5 \\
1 \cdot 9 \\
34 \cdot 0 \\
1 \cdot 0\end{array}$ & $\begin{array}{r}50 \\
25 \\
100 \\
50 \\
\cdots\end{array}$ & $\begin{array}{r}22 \cdot 3 \\
4 \cdot 6 \\
1 \cdot 9 \\
17 \cdot 0 \\
\quad \cdots\end{array}$ \\
\hline & $\cdots$ & $\ldots$ & $45 \cdot 8$ \\
\hline
\end{tabular}

Similar methods applied to some of the other hybrids give the following gametic fertilities:-

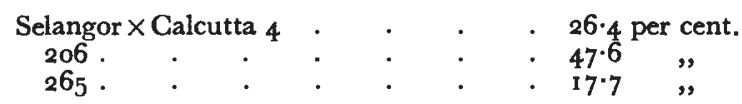

These values are all lower than observed ones $(\S 4)$, and the reasons for the discrepancies may be (I) that convergent chains of four were sometimes misinterpreted as two bivalents and (2) that, and probably more important, some morphologically sound grains were chromosomally unbalanced ; this is supported by the evident variability in size (Dodds, I943 ; table 4). It appears, therefore, from the calculations that the hybrids can hardly be heterozygous for more numerous interchanges than those postulated.

\section{(iii) The deficiency of homozygotes}

The segregation of 9 interchange heterozygotes to 1 homozygote in family 206 deviates significantly from an expected I : I ratio. Similarly the interchange gamete from Pisang Lilan had functioned in every member of family 265 . Three possible explanations of the deficiency of homozygotes in the progeny of Pisang Lilan may be suggested. (I) Elimination may be gametic-the " normal " chromosomes may carry a pollen lethal which is lost occasionally by crossing over to give a homozygote such as 206 (9). (2) Elimination may occur in the young zygotic stage by means of a system of complementary lethals. Although this may be expected to be reflected by seed yield data, there is no evident difference in seed yield between the seeded diploids self-pollinated and pollinated by Pisang Lilan (table 2). These data, however, are derived from different bunches pollinated at different times and too much weight may not be placed upon the comparison. The situation is ideally adapted to analysis by a new statistical method of assessing pollen effects on seed yield (unpublished) and is being approached thus. (3) Elimination may occur at germination or in the young seedling stage. Again, too many variables 
are concerned in germination to justify the collation of ordinary greenhouse records. Statistical tests of germination will have to be conducted concomitantly with the comparisons of seed yield mentioned above.

\section{STERILITY AND THE GENETIC BACKGROUND}

The virtually complete female sterility associated with parthenocarpy has been established by Dodds (1943). It was also shown (Dodds, 1945) that failure to achieve roo per cent. set of ovules in Selangor resulted not from any cytological cause, but from a genotypically controlled failure of fertilisation, so that only about $5^{\circ}$ of the 130 ovules in a receptive finger developed into seeds. Calcutta 4 sets about 80 seeds per ovary. In plant 1590 , with persistent fruits (an earlier product of the same cross that gave 265), the situation was complicated by structural hybridity. However, some sound and presumably balanced embryo-sacs occurred and were fertilised, but the seeds died at various stages towards maturity. Female sterility was complete.

Does "persistency" affect female fertility? To answer this question the mean seed yields of the non-parthenocarpic plants of 206, 265 and Selangor $\times$ Calcutta 4 (table 3 ) are compared in table 7

\section{TABLE 7}

\section{Female fertilities for non-parthenocarpic hybrids}

Numbers of siblings in bold-face type. Mean numbers of seeds per ovary observed in 206 and 265 derived from backcrosses ; in Selangor $\times$ Calcutta 4 , from backcrosses and selfs. The fermale fertility, brackets, of the sterile male parent Pisang Lilan is assumed to be potentially the same as that of Selangor.

\begin{tabular}{|c|c|c|c|c|c|}
\hline \multirow{3}{*}{ Hybrid } & \multirow{3}{*}{$\begin{array}{l}\text { Observed } \\
\text { per cent. } \\
\text { gametic } \\
\text { fertility }\end{array}$} & \multicolumn{4}{|c|}{ Mean numbers of seeds per ovary } \\
\hline & & \multirow{2}{*}{ Obs. } & \multirow{2}{*}{ Calc. } & \multicolumn{2}{|c|}{ Observed in parents of hybric } \\
\hline & & & & Female & Male \\
\hline $\begin{array}{l}206-5 \\
265-13 \\
\text { Selangor } \times \text { Calcutta } 4:\end{array}$ & $\begin{array}{l}60 \\
20 \\
40\end{array}$ & $\begin{array}{r}35 \cdot 9 \\
0 \cdot 4 \\
28 \cdot 4\end{array}$ & $\begin{array}{l}16 \text { or } 10 \\
20 \text { or } 32\end{array}$ & $\begin{array}{l}50 \\
80 \\
50\end{array}$ & $\begin{array}{l}(50) \\
(50) \\
80\end{array}$ \\
\hline
\end{tabular}

with their expected yields estimated from the observed gametic fertilities of these hybrids and the seed yields of the seeded parents (table 2). Using either the observed seed yield of Selangor or that of Calcutta 4, alternative estimates can be made of the expected seed yields of 265 and Selangor $\times$ Calcutta 4 . Both estimates for each are given in table 8 as a necessary compromise in the absence of a value for the seed yield of a hybrid between Selangor and Calcutta 4 that is not heterozygous for two interchanges. 
The comparisons show that the seed yield of Selangor $\times$ Calcutta 4 agrees with, or even exceeds expectation, whereas those of the persistent fruits of 206 and 265 are lower than would be expected. In these two hybrid families, therefore, a reduced seed yield is associated with the genetic background of the homozygous recessive $\mathbf{p p}$, and this suggests that some, at least, of the modifiers of parthenocarpy diminish female fertility.

\section{DISCUSSION}

\section{(i) Parthenocarpy}

Different rates of development and amounts of edible pulp were observed in siblings of 206 and 265 . Thus the expression of $\mathbf{P}$, the gene controlling the formation of edible pulp, may be considerably modified. Again, the production within the same family of partially fertile parthenocarpic plants and partially sterile non-parthenocarpic plants shows that there are genes that directly affect female fertility either in the presence or absence of $\mathbf{P}$. Thus the possibility appears that a completely sterile edible fruit should be considered as resulting from two separate but interdependent genetic systems ; one concerned with the production of edible pulp; the other with the imposition of female sterility. The only offspring raised from edible diploids other than Pisang Lilan are two plants of the parentages Palembang ("type 2 I") $\times$ Calcutta 4 and Palembang $\times$ Selangor (Dodds, I943); the former is fully parthenocarpic and virtually sterile, the latter parthenocarpic but, like 206 (I), partially female-fertile. Thus in Palembang also, parthenocarpy results from the action of a dominant gene and the $F_{1}$ shows a breakdown of the genetic structure.

The conclusion may be drawn that the established edible diploids are highly selected genetic structures and had sexual ancestors that were functional as female parents until seed-sterility became established.

Stout (1937) has shown that stenospermocarpy in grapes is apparently inherited as a dominant, and that some commercial types are heterozygous. Stenospermocarpy is the term used for the formation of fruit with aborted seeds after fertilisation or, at least, entrance of pollen tubes into ovules.

\section{(ii) Interchange}

Interchange hybridity was shown to occur in established edible diploids by Dodds (1943), and in this study it is shown also to occur in the hybrid progeny of the only known male-fertile edible diploid, Pisang Lilan, and in a hybrid between two distinct seeded diploids. Heterozygotes show failure of chromosome pairing with associated partial sterility.

It will be recalled that, with the exception of one plant, all progeny from crosses using Pisang Lilan as male parent with seeded diploids, 
were heterozygous for its interchange, and from this the regular elimination of interchange homozygotes was inferred. But if a casual interchange was fixed before the incidence of parthenocarpy, its selective advantage would presumably have to be great ; for interchange has been shown to cause much gametic sterility. However, vegetative persistence might compensate for this, especially in a plant with a large margin of reproductive safety (Darlington, I929; Darlington and Gairdner, 1937). Alternatively, the interchange may have occurred after the incidence of parthenocarpy but before the loss of sexuality. Primitive agriculturists would select parthenocarpic types having the fewest seeds and so a casual interchange would be automatically selected in the heterozygous condition on account of, rather than in spite of, the sterility it caused.

A different type of interchange hybridity was observed in Selangor $\times$ Calcutta 4. The parents of this hybrid could not cross in their natural habitats, i.e. Galcutta 4 from Burma and Selangor from Malaya, and they are regarded as being representative of two subspecific groups of $M$. acuminata. It appears, therefore, that interchange has accompanied evolutionary divergence much as in Datura (Blakeslee, I929; Bergner et al., I933; Blakeslee et al., 1937). It may be inferred similarly from the work of Peto (1934) that his material of Lolium perenne and its variety multiflorum were homozygotes differing in segmental structure, although the consequences of hybridity were seen in the $\mathrm{F}_{1}$ only as a reduction of gametic fertility (cf. Stebbins, 1945).

Some of the edible diploids in cultivation combine characters of these two groups of $M$. acuminata, and also show interchange behaviours similar to those observed in Selangor $\times$ Calcutta 4 and 265 . Thus the metaphase associations recorded for Bande ("type 22 ") and Sucrier ("type 19") indicate heterozygosity for two and for three interchanges. By analogy with 265 , it may be suggested that these two clones are parthenocarpic products of a hybrid swarm between the two "races" of $M$. acuminata. They might be expected to be about as fertile as 265 . Their effective sterility must be attributed to the accumulation of unselected hybridity by minor structural changes in the course of clonal existence. This, of course, would make impossible any direct test of the hypothesis of their origin. Here also, interchange hybridity has been selected on account of, rather than in spite of, the concomitant sterility.

Another edible diploid, Palembang, resembles Pisang Lilan in being heterozygous for a single interchange and in having certain of the phenotypic characters of the Malayan race of $M$. acuminata. Its hybrid with Calcutta 4 has a potential ring of six chromosomes at meiosis like that found in some members of 265 . Thus segmental identity with Pisang Lilan is suggested and the behaviour of Palembang supports the hybrid origin of the edible diploids. 


\section{(iii) Mistiming}

Swanson and Nelson (1942) have described various errors of spiralisation and abnormalities of the spindle in Mentha. An interesting parallel appears to exist between it and Musa in that the misbehaviours are confined to the first meiotic division. It is inferred that in both cases the abnormalities are primarily those of timing and are in some way dependent on the conditions of spiralisation and movement peculiar to the first meiotic division. In Festuca-Lolium (Darlington and Thomas, 1937), on the other hand, the second division and in maize with divergent spindles (Clarke, 1940), the second and pollen grain divisions are also affected. These cases are therefore probably different from Mentha and Musa since it is difficult to envisage spindle abnormalities initiated in the first division as a consequence of its own peculiar character operating in subsequent cell-generations.

As in the case of the formation of polyploid spores by interspecific hybrids (Dodds and Simmonds, r946), the cause of mistiming (in interspecific hybrids) is unknown. It does, however, seem likely that these peculiarities result from an upset of nucleic acid metabolism at meiosis. A further pointer in this direction is the observation of bridges without fragments in Pisang Lilan and its hybrids.

\section{SUMMARY}

I. A female-sterile edible (parthenocarpic) banana, Pisang Lilan, was crossed as male parent with three of its relatives, seeded strains of Musa acuminata, all being diploids $(2 x=22)$. All three families segregated in the first generation for parthenocarpy. In two of these, parthenocarpy was shown to result from the action of a dominant gene, $\mathbf{P}$, the expression of which is subject to the action of modifiers.

2. A few parthenocarpic plants were not completely femalesterile. Non-parthenocarpic plants were less fertile than expected and we suggest that certain specific female-sterility genes are responsible and are acting as modifiers of $\mathbf{P}$.

3. Pisang Lilan is heterozygous for one interchange. All but one of 35 first cross plants were heterozygous for this interchange and the elimination of interchange homozygotes is therefore inferred.

4. The one exceptional hybrid was cytologically regular. Its effective structural homozygosity, combined with parthenocarpy and diploidy, is conclusive proof that parthenocarpy is independent of structural hybridity and polyploidy in the banana complex.

5. A cross between two geographical races of $M$. acuminata was heterozygous for two interchanges.

6. Maximal chromosome associations rarely or never occurred in the various interchange heterozygotes. Combinations of univalents, bivalents and multiple chains replaced potential rings. These cytological observations are correlated with the consequent gametic sterility. 
7. Observations in some of the hybrids of errors of spiralisation, orientation and movement of the chromosomes, bridges without fragments and irregularities of the spindle are recorded.

\section{REFERENCES}

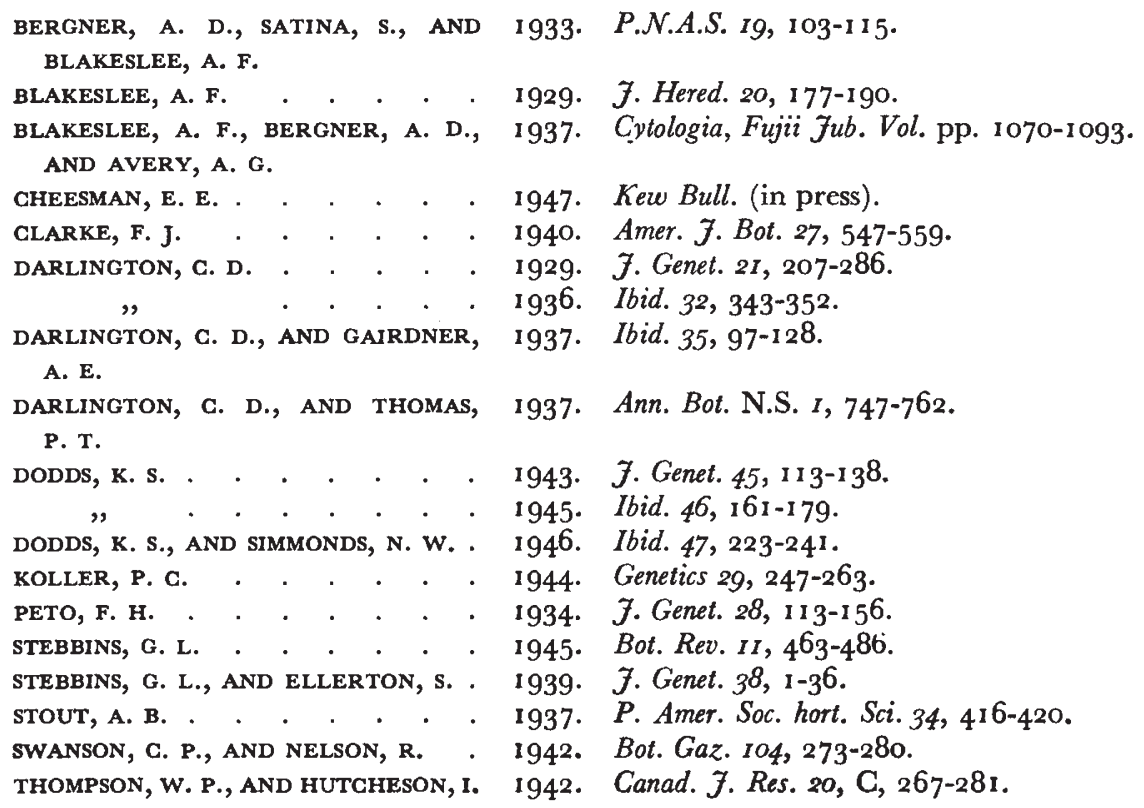

